\title{
From a lecturer to a researcher: a three- stage process of science teachers' professional development in mainland China
}

\author{
Jing Lin(1)
}

Correspondence: linjing@bnu.edu. $\mathrm{cn}$

Collaborative Innovation Center of Assessment for Basic Education Quality, Beijing Normal University, Beijing, China

\begin{abstract}
Established in 1949, the People's Republic of China has gone through 70 years of history. From China's initial inception to the modern day it has grown quickly and become a major force on the world stage, the basic education in mainland China has contributed to cultivating student's talents and developing qualified workers. Specifically, in the 1980s, after implementing a national policy of economic reform and opening up mainland China, China has started a continuous reform in basic education aiming to shift the examination-oriented educational system to literacyoriented education so as to help students to become modern productive citizens in the twenty-first century. Moving into the twenty-first Century China expanded its education infrastructure and instituted compulsory education from grades 1 through 9, the law was intended to create a compulsory 9-year education. This first round of educational reform began in 1986 helping to ensure every child went to school. The second round began in 2001 when the Ministry of Education promulgated new curriculums, which put forward several new philosophies related to the implementation of literacy-oriented education for the first time in mainland China. The third round began in 2012 when the 18th National People's Congress put forward the fundamental goal of the education named Lideshuren, which means the basic education must make efforts for students' development in moral and core competencies, pushing reforms related to human-centered and quality-oriented education to develop students to be more capable in the twenty-first century. Teachers are the key to improving education quality. Each basic education reform in mainland China has triggered a paradigm shift in teacher education. In particular, the first-round reform started in the 1980s has caused mainland China to attend to the professionalization of teachers. Three reforms in science teacher professional development have occurred in the past 30 years. The professional identity of science teachers changed from that of the lecturer in the science classroom to that of the facilitator of science beliefs and is morphing into that of a practice-based-researcher in science teaching. This paper outlines the characteristics and effects of the threestage Chinese science teachers' professional development. It also points out the difficulties and challenges science teachers currently meet in professional development. Hence, the paper provides a case for creating a team of professional science teachers in developing countries. This effort will provide an exemplar to help (Continued on next page)
\end{abstract}


(Continued from previous page)

improve students' scientific literacy all over the world.

Keywords: Science teacher professional development (STPD), Double-base teaching, Scientific literacy, Key competencies

\section{Introducation: the basic education in mainland China}

The People's Republic of China, founded on October 1 of 1949, is located in eastern Asia, on the west coast of the Pacific Ocean. It is a unified multi-ethnic country composed of the Han nationality and 55 other ethnic groups. It is also the most populous developing country in the world with a population of 1 billion 395 million at the end of 2018. China's land area ranks third in the world (State Council 2019). The provincial administrative division is divided into 23 provinces, 5 autonomous regions, 4 municipalities directly under the Central Government, and 2 special administrative regions. The common language is Mandarin and standardized Chinese characters.

At its founding, the People's Republic of China had to start from scratch for everything, including its educational system. In 1949, there were no more than 290 thousand schools for basic education. With the rapid expansion, there are about 610 thousand primary schools, 64 thousand middle schools and 14 thousand high schools in 1998. Due to the requirement of one child policy, the number of the primary and middle schools decreased. Mainland China has 162 thousand primary schools, 52 thousand middle schools and 24 thousand high schools in the end of 2018 (Ministry of Education 2018). The number of students in the schools in each year is shown in Table 1 . There are 9730.9 thousand primary and middle school teachers, and 1812.6 thousand high school teachers in 2018 (Ministry of Education 2019).

The basic education system was modeled the education system and philosophies of the former Soviet Union (circa 1949-1970), emphasizing "intellectual education first" and focusing on the double-base teaching philosophy (Peng et al. 2016). The doublebase teaching philosophy promoted the idea that schools and teachers place more attention on students' mastery of basic knowledge and skills, while neglecting the development of other literacies (Lin 2002). A 10-year school basics education system consisted of 5 years of elementary school, 3 years of secondary school, and 2 years of high school education (Yang 2006). Using the textbooks of the former Soviet Union as a model, the People's Education Press prepared the textbooks for the whole country (the People's Education Press 2010, p.81-98; Liang et al. 2011, p.11-15). Textbooks consisted of text for the separate science disciplines i.e. primary general knowledge, physics, chemistry, biology, and geography. However, due to the shortage of teachers, local schools could not implement these courses as required (Lin 2016, p.171-174). In the 1970s the "Cultural Revolution" interrupted the developmental process of basic

Table 1 Student number in the schools in different year (ten thousand)

\begin{tabular}{llll}
\hline School & 1949 & 1998 & 2018 \\
\hline Primary School & 2439 & 13,954 & 10,339 \\
Middle School & 95 & 5363 & 4653 \\
High School & 32 & 938 & 3935 \\
Special Education & 0 & 36 & 66 \\
\hline
\end{tabular}


education. In the 1980s, mainland China implemented policies for economic reform and promoted openness to exploration of the Chinese road to socialist modernization. Hence the basic education reform also ushered in an era of rapid development (Shi and Zhang 2008).

In 1983, Former National Leader of the People's Republic of China Deng Xiaoping instructed, "education should be oriented toward modernization, toward the world standard and toward the future." In 1985, after the national basic education field investigation and interviews with teachers, students and parents, the Central Committee of the Communist Party of China issued The Decision on the Reform of the Education System to rebuild the basic education system which was interrupted by the "Cultural Revolution." The Ministry of Education carried out a series of adjustments and reforms in the primary (grades 1 through 6) and middle school system (grades 7 through 9) and curriculum (the People's Education Press 2010, p.11-46). First, the primary to high school education was changed to grades 1 through 12 (i.e., 6-years-3-years-3-years); second, revision of all of the syllabus for each discipline occur to place content at an age appropriately level for students; third, to reform the textbook research and development system and to establish the National Review Committee to review and improve the quality of the textbooks developed by the People's Education Press. In 1986, the State Council promulgated The Compulsory Education Law to promote a nine-year compulsory educational system for the primary and middle schools. This was an effort to further strengthen basic education for all children. In 1993, the State Council enacted The Teacher Law to promote teachers' status and put more effort into enrolling and training teachers. In 1995, The Teacher Qualifications Regulation was issued, and the teacher qualification application, examination and certification system were implemented.

The shortage of teachers has been a major dilemma in education for a long period; since the founding of the People's Republic of China (Zhou 2014). Therefore, in addition to the construction of teacher training schools and normal universities to cultivate the basic education of teachers, the Ministry of Education also recruited a large number of "temporary teachers" to supplement the teacher shortage (Yang 2006). In order to ensure that every primary and middle school could achieve basic teaching quality, the Ministry of Education also required local education administration departments to set up teaching and research institutes. These institutes established in 1953, select excellent teachers as full-time teaching and research staff (TRS for short), to provide guidance for teachers' daily practices and managed teacher growth (Liang et al. 2011, p. 2-10).

The reforms and opening of China in the 1980s made Chinese people aware of the gap between mainland China and developed nations in science, technology and education. At the National Education Conference in 1989, the Ministry of Education requested the provinces of Zhejiang and Shanghai to take the lead in the reform of science curriculum (Yu 2002, p.73-79). Zhejiang canceled physics, chemistry, biology, and geography, set up integrated science curriculum in middle schools, and began to use integrated science textbooks in the autumn of 1993 (Yu 2002, p.80-92; Guo 2002, p.100-106). In contrast, Shanghai set up two coexisting kinds of science curriculums for schools and students to choose from. The choices were integrated science and separated sciences (Yu 2002, p.126-130).

In 2001, after studying and learning about the curriculum innovations of more progressive countries, the Ministry of Education abandoned the syllabus, promulgated the 
curriculum standards with literacy goals for basic education. The discipline of primary general knowledge was changed into primary science, the integrated science and separated sciences were set up for middle school education, and only separated sciences were taught in high school education (Zhu 2002, p.16-27). Drawing on the 1996 edition of The National Science Education Standards of the United States, all new science curriculums used scientific inquiry as the main goal and approach to content and strategy in science teaching and learning (Ministry of Education 2001a, 2001b). Science teachers implementing these new approaches faced conflicts and confrontation related to education beliefs and teaching conceptions at that time (Lin 2009, p.116-165; Liu et al. 2012). After more than 10 years of efforts, the beliefs and goals of new curriculum were basically affirmed by science teachers (Liu 2012). In 2012, the National People's Congress asked to further deepen quality education and put forward the fundamental educational goal of Lideshuren, which strengthened moral education and promoted learner's all-round development (China Education Newspaper 2014). In order to promote Lideshuren education, the Ministry of Education issued the revised curriculum standards for compulsory education and high school education in 2013 and 2017 respectively. These calls deepened the literacy-oriented curriculum reforms of the time. As a result, Chinese basic education reform has developed from a shift in knowledgebased, exam-oriented education to literacy-oriented education This call goes further and also promotes moral-based literacy education.

\section{The initial stage of STPD in mainland China: as a lecturer focusing on double- base teaching}

The Chinese culture has lasted for over 5000 years, which always puts Tao first (Meng 2000). Tao is a philosophical concept and was first proposed by Lao Tzu which means the reason or the law for everything. Private schools in ancient times only taught learners The Four Books (The Great Learning, The Doctrine of the Mean, The Confucian Analects, and The Works of Mencius) and The Five Classics (The Book of Songs, The Book of History, The Book of Changes, The Book of Rites and The Spring and Autumn Annals) to understand Tao. Science and technology, including the Four Great Inventions of ancient China were considered to be the skills practiced by lower status Chinese and were considered base (Meng 2000). Although science education was still not an important core part of Chinese basic education for a long period, it has been included in the curriculum system with corresponding textbooks and teachers since 1949 (Liu 2012; Wang 2011; Lin 2011). In particular, physics and chemistry were the entrance exam disciplines of high school and university, so the teacher teams of these two disciplines have been well developed over time (Wang 2011).

\section{Collective lesson preparation helped science teachers to survive in class}

For a long time, pre-service and in-service education for science teachers was separate (Lin 2015, p.58-62). Normal universities were only responsible for the "output" of new teachers with certain disciplinary knowledge. However, these new teachers had only 1 or 2 months of educational internship experience. These new teachers were known as "semi-finished products." The local teaching and research institute mainly handled the teacher's entry training and in-service training. Collective lesson preparation was the 
main strategy for TRS to teach and develop teachers working hand-in-hand with each other (Cong 2011, p.151-165).

In order to improve the ability of teachers to better extend compulsory education, in the late 1980s, a system of teaching and research institutes, which is organized at provincial, municipal, and county levels, conducted experience exchanges within the system (Liang et al. 2011, p.105-121). Because the number of science teachers in each school was small, it was a better practice to let the Counties manage local teachers and to conduct biweekly lesson preparation activities. In schools with poorer conditions teachers only has access to county-based lesson planning every other week. While teachers with better working conditions had access to both county and school-based lesson preparation each week. The municipal teaching and research institutes organized seminars on lesson preparation which was considered the backbone of teaching for all counties every 2 months. The provincial teaching and research institutes held one or two seminars of lesson preparation across the province every semester (Cong 2011, p.307-341).

With the textbooks provided by the People's Education Press and the laboratory materials uniformly provided by the local educational equipment stations, the task of collective lesson preparation for teachers was to figure out how to teach in the classroom. As a result, teachers only had a "teaching" perspective, but no "curriculum" perspective on science education (Lin 2013a). Under the leadership of the TRSs, the collective lesson preparation focused on teaching objectives, foci, and difficulties of each lesson. The teaching objectives were basically all about content knowledge. The TRS themselves or other experienced teachers provided participants with lesson plans for each lesson and explained in detail about how to break through the foci and difficulties, to better achieve the teaching objectives. Correspondingly, the teaching strategies proposed by the collective lesson preparation activities were single style, mainly lecture, or accompanied by certain demonstrations of experiments, wall charts or models (Lin 2013a, 2013b; Qiao et al. 2017). The People's Education Press collected excellent lesson plans from all around the country and published them into books for referencing by teachers. Since such lesson preparation highly focused on the teaching of teachers but neglected the learning of students, the same lesson plans naturally had different effects on students in different teachers' classrooms (Lin 2013b; Sargent and Hannum 2009).

\section{Teaching competition improved science teachers' skills for classroom teaching}

In order to improve the quality of classroom teaching, the People's Education Press led the TRS to establish various national teaching associations for different disciplines of teachers (Cong 2011, p.265-276). The associations held annual teaching competitions across the country, and provided excellent examples to guide the development of teachers' teaching skills. For that purpose, local teaching and research institutes organized county, municipal, and provincial competitions in order to select outstanding teachers to participate in national competitions.

Unlike collective lesson preparation focusing on helping teachers in designing lesson plan, the teaching competitions not only stimulated science teachers' motivation to study curriculum and improve teaching skills, but also offered science teachers the 
opportunities to observe excellent science classroom teaching (Cong 2011, p.265-276). In addition, to achieve good results in national competitions, local TRS also gradually focused on teachers' performance in the classroom and increased activities related to classroom observation and reflection for teachers.

However, influenced by behaviorism learning theory, science teachers' observation and discussion on classroom teaching often paid attention to how teachers could better control and manage the classroom so that students could better coordinate with teachers' lectures, instead of communicating with and responding to students' learning (Lin 2002). The award-winning teachers continued to only implement one model of education. This model was often teacher-centered or knowledge-centered teaching with essential lecture and more exercises.

The phenomenon of only a teacher centered approach commonly occurred in the science classroom. Instead of making students truly understand and apply knowledge, many science teachers adopted a mountain of exercises on paper to help students get high sores in the exams. Hence, science education was criticized as shrinking to nothing but knowledge (Yuan 1999). Further, biology and geography were eliminated from the national university entrance exam disciplines in order to reduce students' burden in the 1990s. In 1999, the Central Committee of the Communist Party of China promulgated Decision on Deepening Educational Reform and Comprehensively Promoting AllAround Education, pointing out that the fundamental task of basic education was to cultivate students' innovative spirit and practical ability. This action required teachers to engage students into self-directed, cooperative and inquiry learning to improve their own competencies in addition to knowledge.

\section{The growth stage of STPD in mainland China: as a converter focusing on scientific inquiry}

The science curriculum standards issued in 2001 proposed many new beliefs stemming from the international science education as it was at that time. Scientific literacy was first taken as the curriculum goals of science education in mainland China in 2001 (Lin 2002). Scientific inquiry that reflected the nature of science was first introduced to Chinese science teachers and received great attention (Liu et al. 2012). The methods of the teaching and learning following the constructivist learning theory were highly recommended, i.e. group study, self-directed learning, project-based learning, etc. These new educational beliefs caused science teachers to be in conceptual conflict with the Kelloff's educational doctrines that science teachers were originally taught in China (Lin 2009, 2013b, p.116-122). First, teachers viewed scientific literacy as a separate concept. They thought that scientific inquiry would inevitably get in the way of students' knowledge learning which put inquiry and knowledge in a duality and in conflict. Second, teachers believed that scientific inquiry only fit for a small number of gifted students. The consequence of this belief was that teachers equated students' inquiry of their own unknown to that of the scientists' inquiry of human unknowns. Third, teachers taught students scientific inquiry in a rigid way, step by step (Lin 2013b). Hence, the Ministry of Education carried out a series of in-service teacher trainings to offer teachers the professional guidance in understanding these new educational beliefs and transferring the beliefs into their teaching behaviors. 


\section{Academic education updated science teachers' knowledge}

Normal universities set up junior college programs, undergraduate programs, and masters programs in the form of correspondence education for in-service teachers of primary and middle schools (Guan 2012, p.88-95). The use of correspondence education meant that the learners studied on their own according to the requirements of the curriculum and were gathered in the universities for face-to-face instruction only in the winter and summer holidays. Science teachers were asked to pass the entrance examination for the correspondence education. Within 2 or 3 years they had to complete study and obtain the required credits to obtain the corresponding academic diploma (Zhou 2014). In the process of academic education, science teachers experienced a systematic learning of modern scientific knowledge and applied new equipment and new technologies in scientific experiments. Many temporary teachers were able to become formal teachers through correspondence education. As a result, the number of teachers with academic degrees for primary and middle school in mainland China improved significantly (Guan 2012, p.89). For example, the percentage of the geography teachers in middle and high schools who obtained the master's degree has increased by $1.3 \%$ in the last 10 years due to the implementation of the new curriculum (Liu 2012).

\section{New curriculum training promoted science teachers' conceptual change}

The implementation of the new curriculum began with the teacher training (Ministry of Education 2001b). The Ministry of Education stipulated that only the teachers who had received official training could teach the new curriculum. Excellent TRS and mainstay teachers were selected to participate in national-level new curriculum training. As seed teachers, they returned to the provinces to assist the provincial TRS in carrying out the provincial-level new curriculum training for teacher representatives at the municipal level. The teachers who had received the provincial training returned to the cities and towns to assist the municipal TRS in conducting training for local teachers who were to teach the new curriculum (Liang et al. 2011, p.188-197). The training content of the new curriculum was generally divided into two parts: general knowledge of education and pedagogical content knowledge of the disciplines. The former contained the educational philosophy and related educational principles of the new curriculum and was usually taught by university professors. The latter included the interpretation of the new curriculum standards, the introduction of the new textbooks, the key points of lesson preparation, and was usually taught by the designers of the new standards and textbooks.

With the gradual advancement in the new curriculum implementation, the Ministry of Education began to carry out distance online training in 2006 to solve the difference between supply and demand for experts to train teachers (Lin 2008). The majority of the materials for online training was the video courses. The designers of the curriculum standards became the trainers and were responsible for developing the video courses. The trainers used dialogue between two or three people and recorded the video. The intent was to do away with lectures in the classroom. In addition, some classic episodes of classroom teaching, or science experiments were inserted into the videos to scaffold the dialogue (Lin 2008). During the online training period, the trainees were required to watch video courses, complete online assignments and participate in online seminars 
within the specified time. The trainees were organized into several online classes. Each class had a monitor and a tutor to encourage and manage the teachers' online learning. The trainers were usually together in one place during the online training period. They held the online seminars, conducted the learning assessments, and gave the trainees timely feedback. As the facilitators of the trainers and local TRS were responsible for online and offline management and supervision of the teachers taking part in the training (Lin 2008).

Drawing on the experience of online training, the Ministry of Education launched the "National Training Program for Primary and Secondary School Teachers" in 2009 under the financial support of the State Council. Priority for this program was given to the central and western regions in mainland China, especially the remote rural areas and minority areas (Guan 2012, 89-90). The program is still in progress till today and the content of the training has been constantly updated.

\section{Assessment reform guided science teachers' development}

In 2008, the Ministry of Education gave each province the right to develop their own version of the university entrance exam and supported the deepening education reform of the time (Ministry of Education 2008). Meanwhile, the Ministry of Education asked the provinces to decentralize the high school entrance exams and allow each city to develop their own entrance exam. In addition, the Ministry of Education issued several documents about assessment reform to guide the proposed local exams. The Ministry of Education insisted that local exams assess a students' ability rather than rote knowledge (Ministry of Education 2001b, 2008). The decentralization of the high-stake exams in across China promoted new curriculum reform, as well as improved the assessment skills of local TRS and teachers. Local exam item designers attempted to prevent students who relied on rote exam preparation from gaining an edge on the exam. To accomplish this, local designers used items related to socio-scientific issues, tested students' understanding and application of knowledge, and pushed science teachers to connect students' inside and outside school experience to their teaching. Some items in the context of scientific experiments tested students' inquiry (using multiple knowledge bases) and scientific thinking, which encouraged science teachers to conduct inquirycentered teaching in their daily practices (Lin 2015, p.55-58).

In terms of the routine teaching assessment, science teachers were guided to establish a view of developmental assessment and to use a variety of methods to promote students' learning. For example, performance-based assessment was encouraged to assess students' experimental skills and principle understanding (Lin 2015, p.55-58). Outside experiments or investigation were encouraged as homework for students. Science teachers also made record cards as a tool to systematically observe and record students' learning performance. Moreover, science teachers made portfolio assessments to examine student learning outcomes in multimodal ways (Lin 2015, p.55-58). Techers also asked students themselves to collect and put any representative works into the portfolio, for example: exam papers, research reports, hands-on products, hand-written newspapers, and award certificates, etc. During the collection students already conducted self-assessment. Teachers further organized students to display the portfolio in stages, and evaluated students' works together with students and parents. 
Textbook compiling improved science teachers' professional level

The basic education reform initiated in 2001 changed the textbook system of the past e.g. "one syllabus, one textbook" and required "a multi-version textbook following the unified standards" (Zhong 2001, p.8-9, p.360-386). According to this textbook reform policy, the whole country actively took part in the development of textbooks. There were 48 versions of new textbooks approved by the Ministry of Education for the primary, middle and high school science education. This illustrated a flourishing movement in the development of science textbooks that has not been seen since the founding of new China (Lin 2015, p.47-50).

Compared with the previous ones, the multi-version textbooks showed significant features. It advocated scientific inquiry, set up new columns such as observation and thinking, experiment and investigation, data collection and analysis, and simulation and modeling (Yang and Liu 2016; Lin 2015, p.47-50). There were large numbers of pictures in these new textbooks that raised readability and fun. In terms of the content it highlighted the understanding of scientific conceptions and principles, the reflected new scientific progress, and the interaction via dialogue with readers (Lin 2015, p.47-50).

A variety of new textbooks provided science teachers and students with a wealth of teaching materials and learning resources, which helped teachers to develop more suitable contexts and methods for students' learning (Lin 2015, p.47-50). At the same time, the process of developing textbook created a good opportunity for enhancing the professional level of the TRS and science teachers who were involved (Liu 2012; Wang 2011). The TRS and science teachers started to systematically think about the science teaching from the perspective of curriculum, took the lead in studying the teaching cases of the new curriculum, and provided professional guidance for peers in the new curriculum training.

\section{The mature stage of STPD in mainland China:as a researcher focusing on scientific literacy}

Based on more than 10 years of theoretical study and practical exploration of new curriculum, several science teachers have constructed a bridge between the theory and practice of science education (Qiao et al. 2017). They have published books and articles in domestic teaching journals of physics, chemistry, biology, or geography. However, it is always complex and hard to transfer beliefs to behaviors, and many science teachers still have a gap between the theory and practice of science education (Lin 2013a, 2019b). It is still a big challenge to Chinese science teachers to become lifelong learners to fulfill their responsibilities in cultivating students through researching their daily practices.

In the same year as the call for Lideshuren, the Ministry of Education promulgated professional standards for K-12 teachers and pressed for teacher professionalization and literacy-orientated education (Shi 2019). On Teacher's Day in 2014 at Beijing Normal University, National Leader of the People's Republic of China Xi Jinping, proposed specific requirements to identify good teachers. The requirement consists of four virtues: (1) ideal and belief; (2) moral sentiment; (3) solid expertise; and (4) benevolence. In 2015, the first round of compulsory education quality assessment was carried out nationwide to examine students' academic performance, physical and mental 
health, and to analyze the main factors affecting education quality (Ministry of Education, 2015). At the same time, the national assessment provided proof for reforming the approaches of educational management and improving the quality of teaching and learning in schools (Ministry of Education 2018). In 2017, the Ministry of Education endorsed revised curriculum standards for high schools. In the revised curriculum core competencies took the central role as the curriculum objective putting forward a new blueprint for quality education. These new regulations and standards act as the guidance for science teachers to become researchers of science education and to deal with daily practices with research thinking and habits.

\section{Creating research community of university teachers and science teachers}

Since the beginning of this century many countries (e.g., United States, France, United Kingdom, Australia, Canada, China) have implemented new rounds of reforms in improving teachers' professional standards. These latest teacher standards unanimously suggest that teachers should be good learners and independently plan their own sustainable professional development. As the education researchers, teachers should cooperate with colleagues, school leaders, students, and parents, to carry out reflective professional practices.

An effective approach to help science teachers to be researchers, is to encourage them to research daily practices with university professors (Bu and Han 2019; Qiao et al. 2017; Zhang and Sun 2018). The theory-immersed observations of university professors help science teachers to identify research questions from within their daily practices. In the process of jointly exploring solutions, the theoretical bases of university professors and the practical experiences of science teachers complement each other to achieve an all-win result (Qiao et al. 2017). Activities such as academic writing and publishing, and oral presentation, improve science teachers' research literacy in abstract and generalization, logical reasoning, and rational thinking among other traits.

University professors studying curriculum and pedagogy are involved in teacher training and development of preservice and in-service science teachers. Teachers and researchers from multiple universities and institutes are helping science teachers to achieve professional development and collaborative research. For example, science teachers collaborate with researchers from the Chinese Academy of Sciences and the Chinese Academy of Engineering to guide students' science research projects and students' engineering design activities respectively. Through collaboration with researchers, science teachers can engage in rethinking, reflecting, and analyzing their daily practices, gradually forming habits for research (Bu and Han 2019; Ryan et al. 2009).

\section{Improving science teaching quality based on national assessment outcomes}

The teaching and research institute of basic education is one of the features of Chinese education (Cong 2011, p.119-129). Over the years, the teaching and research institute has overseen all assessment of schools and teachers (Cong 2011, p.201-224). Thus, science teachers generally lack the sense of self-determination in assessment, and are accustomed to being evaluated, judged, and informed by others. The national quality assessment of basic education is aimed to guide not only the public's perspective on 
education quality, but also data-driven education reform within the education system (Ministry of Education 2018). This activity acts as scaffolding for science teachers to become researchers and to improve their daily practices based on the data analysis of national science education quality assessment.

First, science teachers should learn to study and interpret the national and local science education assessment reports. Second, find research questions through connecting the assessment data to their daily practices with certain professional support. Third, learn to diagnose and monitor their classroom teaching quality through assessment. Fourth, learn to report their data-driven teaching research and try to share with academic community.

Lack of a foundation in education measurement is not only a weakness of science teachers, but also a weakness of some educational researchers. The reason is, that in normal universities, education measurement is a compulsory course for learners majoring in psychology but not education. Learners majoring in education are required to take the course, Education Research Methodology, and have the option to take an education measurement course. The curriculum, mode, and teaching practice of pre-service teacher education need further reform in order to cultivate quality pre-service teachers to be competent for the mission of developing students' scientific literacy (Xun 2019).

\section{Modernizing science teachers' literacy through STEM education}

With the rapid development of science and technology, a need for a citizen to be scientifically literate is contently increasing. STEM education is both an opportunity and a challenge for science teachers in primary and secondary schools. However, STEM is one manner to cultivating students' modern scientific literacy (Lin and Shi 2019). STEM education is an educational idea and measure to cultivate talents in the twentyfirst century (Bybee 2013, p.33-40). The unique value of STEM education lies in providing learners with realistic and meaningful learning situations through integration of disciplinary content and practices (Lin et al. 2019b). Learners activate higher-level thinking, positive emotions, and engage in complex problem solving. These activities are conducive to comprehensive improvement of learners' core competencies through integral application of their cognitive skills, scientific understanding, and scientific attitudes (Lin et al. 2019b). To be the lifelong learners and overall develop their own literacy, it is essential for science teachers to conduct research on STEM education.

However, according to an existing survey, Chinese science teachers have insufficient understanding and application of interdisciplinary content, engineering, and technology, so their self-efficacy in STEM education is not high (Lin and Shi 2019; Sun et al. 2014). That means it is also a challenge for science teachers to create authentic problem situations which connect with contemporary technology and engineering to enhance students STEM literacy. Research indicates that teacher learning as adult learning is supposed to have practical importance and be driven by internal motivation (Durksen et al. 2017). Teacher reflection is supported by means of individual supervision in teacher leaning (Dori and Herscovitz 2005). As action researchers, teachers should undertake their learning through collaborative inquiry in their workplace to improve their own practices (Vrikki et al. 2017). Hence, science teachers in primary and 
middle schools should be guided and supported to be the pioneers in STEM education. Science teachers themselves should experience STEM activities through project-based learning, then learn to design and teach STEM activities in their classrooms (Krajcik and Czerniak 2018, p.1-10).

The idea of "teachers as researchers" has been put forward since the 1960s (Stenhouse 1975, p.124-125). The teachers as researchers' concept is still difficulty for teachers despite 60-years of work. For example, pre-service and in-service science teachers need to develop the ability to engage with information and communication technology along with traditional culture and multicultural understandings. The rural science teachers need teaching resources and the chance to collaborate with a professional community. There are still many part-time science teachers in the primary schools, especially in rural primary schools. Many of these rural teachers lack a professional background in science and science education. In addition, a reform in teacher assessment is needed to stop assessing teachers' performance only based upon their students' exam scores. There is still a long way to go for science teacher education in mainland China.

\section{Conclusions}

Overall in the past 30 years, the basic education reform in mainland China has created a paradigm shift in science teachers' professional identity. In some ways the number of reforms has allowed China to engage in continuous experimentation around the development of the integration of the practices and content of science along side the development of its educational system. This uniquely situates China as a potential leader for other developing countries due the large economic, research, human, and infrastructure investments China has made in science education. In many ways the larger reforms have been encapsulated in the changes science teaching has undergone. Science teachers have changed from the lecturer in the science classroom to the facilitator of new beliefs and is gradually becoming the researcher of science teaching and learning. The unique contribution that the TRS of China's basic education, play an important role in teachers' development, and have spearheaded the change from leader teachers to researchers through collaborative research with universities and research institutes.

Many countries are facing difficulties and challenges in science teacher's professional development. Looking back on the three stages of Chinese science teachers' professional development, some specific measures, and reflections are offered to provide evidence for creation of a team of professional science teachers for developing countries. This is particularly possible given the large number of teachers and students in the Chinese educational system. Success in the Chinese system would allow for some level of translation to other developing countries and may allow China to provide the clarion call for others to reform their educational systems. Incorporation of these activities will allow developing countries to make a joint effort in improve students' scientific literacy all over the world.

Abbreviations

ELL: English Language Learner; LOI: Language of Instruction; MIA: Multimodal Instructional Approach 


\section{Author's contributions}

Summary the professional development of science teachers in mainland China in three stages and offer a case with creating a team of professional science teachers for the developing countries so as to make joint efforts to improve students' scientific literacy all over the world. The author read and approved the final manuscript.

\section{Author's information}

Dr. Jing Lin is a science education scholar in mainland China. Currently, she serves as the director of Science Education Quality Development Department in Collaborative Innovation Center of Assessment toward Basic Education Quality at Beijing Normal University. She is also a core expert in the "Professional Support for Science Curriculum (Grade 7-9) Experiment Program of Ministry of Education of China". In 1993, she started to participate in Integrated Science Curriculum Reform in mainland China. Once as a teaching and research staff and the director of the teaching and research office, she was also engaged in compiling science textbooks and the evaluation as well as reform of Senior High School Entrance Examination in Zhejiang. In the past 5 years, as a principal or core member, Dr. Lin has conducted 15 national-level and provincial-level research projects, published more than 30 papers in SSCI and CSSCl and more than 10 books in Chinese.

\section{Funding}

Supported by the 13th Five-Year Plan for Beijing Education Science 2016 Project (Grant No. CEFA16030), Beijing Normal University Education Foundation (Grant No. 50006004)

\section{Availability of data and materials}

Not applicable

\section{Ethics approval and consent to participate}

The data collected from this article did not involve human subjects so no human subjects approval was necessary.

\section{Consent for publication}

The authors agree that this article will be published in the APSE journal.

\section{Competing interests}

The author declares that she has no competing interests.

\section{Received: 13 August 2019 Accepted: 13 November 2019}

Published online: 02 December 2019

\section{References}

Bu, Y., \& Han, X. (2019). Promoting the development of backbone teachers through university-school collaborative research: The case of new basic education (NBE) reform in China. Teachers and Teaching, 25(2), 200-219. https://doi.org/10.1080/ 13540602.2019.1568977.

Bybee, R. W. (2013). The case for STEM education: challenges and opportunities. Arlington: NSTA Press.

China Education Newspaper. (2014). Ba lideshuren zuowei genben renwu TTake Lide Shuren as the fundamental goal for education]. China Education Newspaper Retrieved from http://www.jyb.cn/opinion/mtzl/201402/t20140219_570475.html. 19 Feb 2014

Cong, L. X. (2011). Chenmo de quanwei: zhongguo jichu jiaoyu jiaoyan zuzhi [Silent authority: the teaching and research institute in China basic education]. Beijing: Beijing Normal University Press.

Dori, Y. J., \& Herscovitz, O. (2005). Case-based long-term professional development of science teachers. International Journal of Science Education, 27(12), 1413-1446. https://doi.org/10.1080/09500690500102946.

Durksen, T., Klassen, R., \& Daniels, L. (2017). Motivation and collaboration: The keys to a developmental framework for teachers' professional learning. Teaching and Teacher Education, 67, 53-66. https://doi.org/10.1016/.jtate.2017.05.011.

Guan, P. J. (2012). Zhongguo duiwu jianshe yanjiu [Research on the construction of Chinese teacher team]. Beijing: Beijing Normal University Press.

Guo, Y. Y. (2002). Cong chuantong dao xiandai: zonghe kexue kecheng de fazhan [From tradition to modern: the development of integrated science curriculum]. Beijing: Beijing Normal University Press.

Krajcik, J. S., \& Czerniak, C. M. (2018). Teaching science in elementary and middle school: A project-based learning approach (5th ed.). New York and Oxon: Routledge.

Liang, W., Lu, L. T., \& Huang, D. (2011). Qiaodong zhongguo jichu jiaoyu de zhidian: zhongguo tese jiaoyan zhidu fazhan [Pushing the foundation of basic education in China: the development of teaching and research system with Chinese characteristics]. Beijing: Educational Science Publishing House.

Lin, J. (2002). Dui ershiyi shiji zhongxue shegnwuxue jiaoyu de sisuo [Reflections on biology education of middle schools in the 21st century]. Middle School Biology, 4, 4-5 Retrieved from http://www.cnki.com.cn/Article/CJFDTotal-SANG200204 002.htm.

Lin, J. (2009). Cong guannian dao xingwei: kexue jiaoshi jiaoxue guannian diaocha yu fenxi [From the conceptions to behaviors: An investigation and analysis on teaching conceptions of science teachers]. Beijing: Beijing Normal University Press.

Lin, J. (2013a). Xiaoxue kexue jiaoshi zhishiguan de diaocha yu fenxi [Investigation and analysis on the conceptions of knowledge of primary science teachers]. Curriculum, Teaching Material and Method, 33(8), 95-100 Retrieved from http:// www.cnki.com.cn/Article/CJFDTotal-KJJF201308017.htm.

Lin, J. (2013b). Shengwuxue gainian de jiaoxue hanyi yu shishi jianyi [Connotations and implementation proposals of biological concepts teaching]. Journal of Tianjin Normal University (elementary education edition), 14(2), 52-55. https://doi. org/10.3969/j.issn.1009-7228.2013.02.012.

Lin, J. (2015). Zongquo kexue jiaoyu fazhan baogao [Report on China's science education]. Beijing: Social Sciences Academic Press. 
Lin, J. (2016). Zhongguo jiaoyu gaige daxi: xueke jiaoxue juan [Education reform in China: discipline teaching]. Wuhan: Hubei Education Press.

Lin, J., Liu, X., Chang, J., Shi, X. (2019a). Developing a measurement instrument for teacher key competencies. Paper presented at the 2019 annual meeting of the American Education Research Association. DOI: 10.302/1431378. Retrieved from the AERA online paper repository.

Lin, J. \& Shi, X. Y. (2019). Analysis of elementary science teacher conceptions of STEM education. Paper presented at the 2019 CAERDA conference in Toronto. Retrieved from https://www.caerda.org/docs/2019_CAERDA_Program_0401.pdf.

Lin, J., Shi, X. Y., \& Wei, W. T. (2019b). Xiaoxue kexue kecheng zhong kaizhan STEM jiaoyu de wenti yu duice [Issues and suggestions for integrating STEM education into elementary science]. Curriculum, Teaching Material and Method, 39(3), 117-121 Retrieved from http://kjjf.chinajournal.net.cn/WKE/WebPublication/paperDigest.aspx?paperlD=591eda9f-6cd7-4 c65-b37e-bd708cc1bd16.

Lin, P. Y. (2008). Dili jiaoshi wangluo yuancheng yanxiu de yiyi he kecheng kaifa chutan [The significances and development of web distance research and training course for geography teachers]. Curriculum, Teaching Material and Method, 28(7), 78, 83-78, 87 Retrieved from http://www.cnki.com.cn/Article/CJFDTotal-KJJF200807016.htm.

Lin, P. Y. (2011). Xin de kecheng linian: dili kecheng gaige shinian de cong renshi zhuanxiang shijian [New curriculum ideas: from knowing to practicing in the ten years of geography curriculum reform]. Basic Education Curriculum, (Z2), 81-86 Retrieved from http://mall.cnki.net/magazine/Article/JCJK2011Z2017.htm.

Liu, E. S. (2012). Yiwu jiaoyu shengwuxue kecheng gaige shinian huigu [A ten-year review of biology curriculum reform in compulsory education]. Bulletin of Biology, 47(11), 3-10 Retrieved from http://www.cnki.com.cn/Article/CJFDTotal-SWXT2 01211000.htm.

Liu, X., Liang, L., \& Liu, E. (2012). Science education research in China: challenges and promises. International Journal of Science Education, 34(13), 1961-1970. https://doi.org/10.1080/09500693.2012.709330.

Meng, J. W. (2000). Yi renwen hangai kexue: xiandai xin rujia wenhuaguan jiqi pianpo [Science covered with human studies: the culture outlook of modern neo-Confucianism and its bias]. Studies in Dialectics of Nature, 16(7), 7-11, 53. https://doi. org/10.3969/j.issn.1000-8934.2000.07.002.

Ministry of Education. (2001a). Guojia yiwu jiaoyu kexue kecheng biaozhun (7-9nianji) [National science curriculum standards of the compulsory education (Gr. 7-9)]. Beijing: Beijing Normal University Press.

Ministry of Education. (2001b). Jichu jiaoyu kecheng gaige gangyao (shixing) The outline of basic education curriculum reform (in trial)]. Retrieved from http://old.moe.gov.cn//publicfiles/business/htmlfiles/moe/s8001/201404/xxgk_167343. html.

Ministry of Education. (2008). Guanyu shenru tuijin he jinyibu wanshan zhongkao gaige de yijian [Suggestions on further promoting the reform of entrance exam of senior high school]. Retrieved from http://old.moe.gov.cn/publicfiles/ business/htmlfiles/moe/moe_711/201001/xxgk_78505.html.

Ministry of Education. (2015). Jianli guojia jiance zhidu cujin yiwu jiaoyu zhiliang tigao [Establish a national assessment system to improve the basic education quality]. Retrieved from http://www.moe.gov.cn/jyb_xwfb/xw_fbh/moe_2069/xwfbh_2 015n/xwfb_150415/150415_sfcl/201504/t20150415 187149.html.

Ministry of Education. (2018). Release of China's first oversight report on quality of compulsory education. Retrieved from http://en.moe.gov.cn/News/Top_News/201808/t20180801_344002.html.

Ministry of Education. (2019). 2018nian quanguo jiaoyu shiye fazhan tongji gongbao [Statistical bulletin of national education development in 2018]. Retrieved from http://www.moe.gov.cn/jyb_sjzl/sjzl_fztjgb/201907/t20190724_392041.html.

Peng, Z. P., Yao, L., \& Huang, E. (2016). Xin zhongguo yiwu jiaoyu puji yu fazhan: licheng yu jingyan [Popularization and development of compulsory education in new China: process and experience]. Journal of southwest university (Social Sciences Edition), 42(5), 74-83. https://doi.org/10.13718/j.cnki.xdsk.2016.05.010.

People's Education Press. (2010). Xin zhongguo zhongxiaoxue jiaocai jianshe shi [History of textbook construction in primary and middle schools in new China (1949-2000)]. Beijing: People's Education Press.

Qiao, X., Yu, S., \& Zhang, L. (2017). A review of research on professional learning communities in mainland China (2006-2015): key findings and emerging themes. Educational Management Administration \& Leadership, 46(5), 713-728. https://doi.org/ $10.1177 / 1741143217707523$.

Ryan, J., Kang, C., Mitchell, I., \& Erickson, G. (2009). China's basic education reform: an account of an international collaborative research and development project. Asia Pacific Journal of Education., 29(4), 427-441. https://doi.org/10.1080/ 02188790903308902.

Sargent, T. C., \& Hannum, E. (2009). Doing more with less: teacher professional learning communities in resource-constrained primary schools in rural China. Journal of Teacher Education, 60(3), 258-276. https://doi.org/10.1177/0022487109337279.

Shi, K. C. (2019). Xin zhongguo 70 nian jiaoshi xingwei guifan liubian: jiyu zhengce wenben de fenxi [The evolution of codes of conduct for teachers in the 70 years of new China: an analysis based on policy texts]. Teacher Development Research, 3(2), 9-13. https://doi.org/10.19618/j.cnki.issn2096-319x.2019.02.002.

Shi, Z. Y., \& Zhang, X. Q. (2008). 30 nian jiaoyu gaige de zhongguo jingyan [Education reform: experience from China]. Journal of Beijing Normal University (Social Science Edition), 209(5), 22-32 Retrieved from http://www.cnki.com.cn/Article/ CJFDTotal-BJSF200805003.htm.

State Council. (2019). Data. Retrieved from http://www.gov.cn/shuju/index.htm.

Stenhouse, L. (1975). An introduction to curriculum research and development. London: Heinemann.

Sun, D., Wang, Z., Xie, W., \& Boon, C. (2014). Status of integrated science instruction in junior secondary schools of China: an exploratory study. International Journal of Science Education, 36(5), 808-838. https://doi.org/10.1080/09500693.2013.829254.

Vrikki, M., Warwick, P., Vermunt, J. D., Mercer, N., \& van Halem, N. (2017). Teacher learning in the context of lesson study: A videobased analysis of teacher discussions. Teaching and Teacher Education, 61, 211-224. https://doi.org/10.17863/CAM.7057.

Wang, L. (2011). Yiwu jiaoyu huaxue kecheng biaozhun shinian shishi huigu [A ten-year review on the implementation of chemistry curriculum standards in compulsory education]. Basic Education Curriculum, (Z2), 62-69 Retrieved from http:// www.cnki.com.cn/Article/CJFDTotal-JCJK2011Z2014.htm.

Xun, Y. (2019). Xin shidai jichu jiaoyu jiaoshi duiwu jianshe de mubiao, neirong yu lujing [Analysis on goal, content and path of teachers building in the new era]. Teacher Education Research, 31(2), 8-14 Retrieved from http://www.cnki.com.cn/ Article/CJFDTotal-GDSZ201902002.htm. 
Yang, D. P. (2006). Cong quanli pingdeng dao jihui jundeng [From equality of right to equality of opportunity: the slot of educational equity in new China]. Peking University Education Review, 4(2), 2-11. https://doi.org/10.3969/j.issn.1671-9468.2006.02.002.

Yang, W., \& Liu, E. (2016). Development and validation of an instrument for evaluating inquiry-based tasks in science textbooks. International Journal of Science Education, 8(18), 2688-2711. https://doi.org/10.1080/09500693.2016.1258499.

Yu, Z. Q. (2002). Kexue kecheng lun [On integrated science]. Beijing: Educational Science Publishing House.

Yuan, Z. G. (1999). Fansi kexue jiaoyu [Reflection on science education]. Primary and Secondary School Management, (12), 2-4. https://doi.org/10.3969/j.issn.1002-4808.2001.02.004.

Zhang, J., \& Sun, Y. (2018). Development of a conceptual model for understanding professional learning communities in China: a mixed-method study. Asia Pacific Education Review, 19, 445-457. https://doi.org/10.1007/s12564-018-9548-3.

Zhong, Q. Q. (2001). In Y. H. Cui \& H. Zhang (Eds.), Jichu jiaoyu kexue gaige gangyao jiedu [An interpretation of the outline of basic education curriculum reform (in trial)]. Shanghai: East China Normal University Press.

Zhou, J. (2014). Teacher education changes in China: 1974-2014. Journal of Education for Teaching, 40(5), 507-523. https://doi. org/10.1080/02607476.2014.956543.

Zhu, M. J. (Ed.). (2002). Zoujin xin kecheng: yu kecheng shishizhe duihua [Entering the new curriculum: dialogue with the implementer]. Beijing: Beijing Normal University Press.

\section{Publisher's Note}

Springer Nature remains neutral with regard to jurisdictional claims in published maps and institutional affiliations.

Submit your manuscript to a SpringerOpen ${ }^{\circ}$ journal and benefit from:

- Convenient online submission

- Rigorous peer review

- Open access: articles freely available online

High visibility within the field

- Retaining the copyright to your article

Submit your next manuscript at $\boldsymbol{\nabla}$ springeropen.com 